\title{
Penyuluhan Dampak Pernikahan Dini bagi Perempuan
}

\author{
Mesta Limbong ${ }^{1}$, Evi Deliviana ${ }^{2}$ \\ 1,2Universitas Kristen Indonesia, Jakarta, Indonesia \\ mesta.violenta.limbong@gmail.com; deliviana@yahoo.com
}

\begin{abstract}
Abstrak
Pernikahan dini adalah pernikahan yang berlangsung di usia yang belum genap 18 tahun. Fenomena tersebut di Indonesia masih menjadi sorotan karena jumlahnya yang semakin meningkat. Padahal, dampak yang ditimbulkan dari pernikahan dini sangat kompleks, terutama bagi pihak perempuan. Salah satu bentuk upaya pencegahan terjadinya pernikahan dini adalah melalui pemberian penyuluhan berisi informasi kerugian atau dampak negatif dari pernikahan dini terutama bagi perempuan. Penyuluhan sebaiknya diberikan kepada berbagai pihak yang dapat berkontribusi untuk menekan angka pernikahan dini, salah satunya adalah guru di sekolah. Interaksi guru dengan murid yang cukup intens, dapat menjadi peluang bagi guru untuk memberikan pemahaman bagi siswa serta orangtua siswa mengenai kerugian atau dampak negatif dari pernikahan dini. Oleh karena itu, pengabdian kepada masyarakat ini memberikan penyuluhan kepada seluruh guru-guru perempuan yang mengajar di berbagai tingkat pendidikan, mulai dari Taman Kanak-kanak (TK) sampai dengan Sekolah Menengah Pertama (SMP) yang ada di wilayah perkebunan kelapa sawit Pekanbaru milik PT. Astra Agro Lestari. Hasil dari penyuluhan yang diberikan adalah bahwa seluruh guru-guru sepakat dan mendukung segala upaya yang dapat menekan angka kejadian pernikahan dini di wilayah perkebunan kelapa sawit dengan meneruskan hasil dari penyuluhan ini kepada siswa-siswa maupun orangtua siswa bahwa pernikahan seharusnya dilakukan saat seseorang telah siap secara mental, sosial maupun fisik. Hal tersebut akan berdampak positif bagi generasi baru yang berkualitas.
\end{abstract}

Kata kunci: pernikahan dini, guru, perempuan

\begin{abstract}
Early marriage is a marriage that occur at age before 18 years old. In Indonesia, this phenomenon still become a spotlight because the increasing amount. Whereas the impact from early marriage so complex, especially for the woman. One of the effort to prevent early marriage is giving the counseling information about the negative effect of early marriage itself, especially for woman. Counseling should be given to every part who can contribute to pressing the number of early marriage, one of them is teacher at school. The intense interaction between the teacher and the students can be opportunities for the teacher to provide understanding for the students and parents about the disadvantages or the negative effect of early marriage. Therefore, this community service provides counseling to all women teacher whose teaching at various levels of education, starts from kindergartens, to junior high school in Pekanbaru oil palm plantations area which owned by PT. Astra Agro Lestari. The result of counseling that had given are all the teachers agreed and support all efforts that can reduce the number of early marriages in oil palm plantations with continue the result of this counseling to the students and parents that a marriage supposed to be done when someone is ready mentally, socially or physically. Those will have a positive impact for new generation of quality.
\end{abstract}

Keywords: early marriage, teacher, woman 


\section{PENDAHULUAN}

Pada tayangan acara televisi Obrolan perempuan terkini (Opini) di tanggal 17 April 2018 mengenai persentase kejadian pernikahan dini di beberapa provinsi di Indonesia, diperoleh data sebagai berikut: bahwa persentase terjadinya pernikahan di wilayah Kalimantan Selatan sebesar 23,87\%, Jawa Timur sebesar 20,38 \%, Jambi sebesar $17,36 \%$, dan wilayah Sulawesi Barat sebesar 20,10\%. Selain itu, diperoleh data bahwa Indonesia adalah negara nomor 2 terbesar di Asia Tenggara setelah Kamboja yang berkontribusi terhadap pernikahan dini, serta peringkat ke 7 di dunia mengenai pernikahan dini. Merujuk Undang-Undang Perlindungan anak Nomor 23 tahun 2002 di Bab I pasal 2 diuraikan bahwa "anak adalah seseorang yang belum genap berusia 18 (delapan belas) tahun, termasuk anak yang masih dalam kandungan". Dari konsep tersebut dapat disimpulkan bahwa menikah dini artinya adalah seseorang yang melakukan pernikahan di saat usianya belum genap 18 tahun, sehingga ia termasuk kelompok usia anak yang masih dalam perlindungan orangtua.

Tayangan televisi Kick Andy tanggal 19 Juli 2018 juga membahas mengenai pernikahan dini dengan mendatangkan pemuda berusia 21 tahun Yoga Andika, penggagas puskesmas remaja "Laskar
Pencerah Tosari" di daerah Jawa Timur, Kecamatan Tosari. Yoga telah mengeluti hal ini sejak ia masih berusia 12 tahun. la dipengaruhi oleh kehadiran mahasiswa yang melakukan pengabdian masyarakat di daerahnya, sehingga Yoga mendapatkan wawasan baru mengenai pentingnya pendidikan dan peluang untuk mengembangkan diri. Yoga juga prihatin dengan teman-teman seusianya yang telah menikah di usia antara 13-14 tahun dengan pasangan seusianya atau kakak kelasnya. la tergerak karena melihat kehidupan remaja yang terkungkung dengan kehidupan yang begitu mudahnya melakukan hubungan yang jauh tanpa menyadari dampaknya. Sejak SD, Yoga menyadari fenomena tersebut terjadi di Tosari. Di SMP ia semakin menyadari bahwa hubungan seks pranikah yang berujung pernikahan dini tidak bisa dibiarkan begitu saja. la lalu melakukan upaya pencegahan pernikahan dini dengan mendirikan puskesmas remaja "Laskar Pencerah Tosari”.

Yoga menggagas Puskesmas Remaja ini untuk mengurangi fenomena pernikahan dini yang sudah turun temurun berlangsung di daerahnya. Pernikahan dini seringkali diakibatkan karena hamil di luar nikah sehingga harus menikah dini. Fenomena ini terjadi pada remaja yang masih duduk di jenjang pendidikan SMP. Penyebabnya seringkali karena 
Volume 2, Nomor 1, Tahun 2020 Hal 321 - 329

kurangnya informasi atas dampak yang akan muncul jika mereka melakukan hubungan seks pranikah dan selanjutnya menikah di usia dini. Kebanyakan dari mereka belum menyadari pentingnya pendidikan bagi masa depan mereka.

$$
\text { Faktor-faktor lainnya yang }
$$

menyebabkan mereka melakukan hubungan seks pranikah dan berujung pernikahan dini adalah karena salah pergaulan atau hubungan yang terlalu bebas sehingga menimbulkan kehamilan yang tidak dinginkan. Hal tersebut terjadi mungkin atas kemauan remaja itu sendiri karena pergaulan bebas, pornografi yang semakin marak, sehingga mereka sebagai anak/remaja tidak mampu memikirkan hal lain yang lebih membangun dirinya ke arah yang lebih baik. Padahal dampak negatif dari peristiwa itu sangat banyak.

Dampak secara biologis adalah remaja yang belum siap untuk melakukan hubungan fisik terhadap lawan jenis, belum lagi dampak mental dan emosional karena mereka masih dalam tahap perkembangan remaja. Di usia remaja yang masih muda, ada kecenderungan remaja untuk mencoba banyak hal yang mungkin hari ini disukai, mungkin waktu esok atau minggu berikutnya berubah menjadi tidak suka.

Pada fenomena pernikahan dini, pihak perempuan seringkali menjadi korbannya. Remaja perempuan yang hamil sebelum menikah, dikondisikan untuk menikah karena adanya tekanan dari masyarakat yang jika tidak menikah, mereka akan menjadi bahan perbincangan. Padahal, dampak dari pernikahan yang terlalu dini bagi kesehatan remaja perempuan dapat menyebabkan peningkatan kematian karena secara fisik mereka belum siap untuk melahirkan. Dampak lainnya adalah mereka kehilangan hak untuk mendapatkan pendidikan, hak untuk mendapat perlindungan dari orangtua, dan kondisi ketidaksiapan mental mereka berbagi peran yang mungkin tidak dapat dilakukan secara optimal sehingga menyebabkan mereka semakin tertekan secara psikologis. Untuk mengurangi fenomena ini, kami berpikir bahwa salah satu pihak yang dapat menjadi agen penyuluh mengenai dampak negatif dari pernikahan dini adalah guru. Peran guru sebagai pendidik bagi siswanya sangat penting, terutama terhadap siswa yang termasuk dalam kategori remaja. Kelompok usia tersebut seringkali menjadi subyek yang terkait di dalam terjadinya pernikahan dini. Penyuluhan yang dapat dilakukan oleh guru tidak hanya berisikan dampak negatif dari pernikahan dini, namun guru dapat juga memberikan penyuluhan bagi orangtua mengenai pentingnya pola asuh orangtua terhadap remaja.

Seperti yang kita ketahui, bahwa remaja adalah individu yang secara emosi masih labil dan secara fisik masih dalam proses pertumbuhan sehingga sangat memerlukan pendampingan. Penting bagi 
Volume 2, Nomor 1, Tahun 2020 Hal 321 - 329

orangtua untuk menyusun pola asuh di bawah usia 18 tahun yang berisi aturan yang jelas sehingga dapat mengontrol perilaku remaja. Secara keseluruhan, orangtua, guru sebagai pendidik, dan masyarakat secara umum perlu memahami dampak negatif yang lebih banyak muncul dari pernikahan dini, sehingga guru-guru mendorong siswa di sekolah lebih kreativitas dalam melakukan kegiatan di sekolah.

Kemajuan teknologi yang begitu pesat juga berdampak terhadap penyebaran informasi yang tidak memperhitungkan jarak, tempat dan waktu. Pada masa lalu, bisa saja pernikahan dini telah berlangsung, tetapi karena perkembangan media dahulu belum sepesat saat ini, sehingga mungkin saja informasi tersebut tidak terdengar. Namun, konsep pernikahan dini saat ini menjadi hal yang tidak tabu dan masyarakat banyak juga yang mengakui dan melegalkan hal ini. Seiring dengan kemajuan teknologi serta adanya perundang-undangan yang melarang pernikahan dini karena dilihat dari perspektif kesehatan dan lainnya, maka timbul permasalahan bahwa pernikahan dini adalah hal yang tidak dianjurkan.

Pernikahan dini sebaiknya dicegah, untuk itu perlu adanya berbagai upaya yang harus disampaikan kepada anak, remaja, orangtua, sekolah (dalam hal ini guru-guru) bahwa pernikahan dini sebaiknya dicegah. Perlunya juga diskusi yang membahas upaya apa yang dapat dilakukan untuk meminimalkan terjadinya pernikahan dini dan meminimalkan dampak negatif bagi perempuan usia remaja.

\section{METODE}

Banyaknya dampak negatif dari pernikahan dini, memunculkan pemikiran bahwa pernikahan dini adalah hal yang tidak dianjurkan. Pada kegiatan pengabdian kepada masyarakat ini, kami menggunakan dua metode yang dapat mengakomodir pembahasan mengenai apa itu pernikahan dini dan dampaknya bagi perempuan, serta upaya apa yang dapat dilakukan oleh para guru untuk meminimalkan terjadinya peristiwa pernikahan dini dan meminimalkan dampak negatif bagi perempuan usia remaja.

Adapun kedua metode tersebut adalah:

1. Metode Ceramah: metode ini berisikan kegiatan penyuluhan kepada guru-guru yang hadir mengenai persentase pernikahan dini di Indonesia, faktor-faktor penyebab pernikahan dini, dampak-dampak dari pernikahan dini, serta solusi yang dapat dilakukan untuk meminimalisir angka kejadian pernikahan dini.

2. Metode Focus Group Discussion (FGD): setelah seluruh materi selesai dipaparkan, penulis meminta seluruh guru yang hadir masuk ke dalam kelompok-kelompok yang sudah dibentuk untuk melakukan diskusi. 
Volume 2, Nomor 1, Tahun 2020 Hal 321 - 329

Setelahnya, penulis juga memberikan ruang tanya jawab mengenai hasil diskusi di tiap-tiap kelompok. Tujuan metode ini dipilih agar pemahaman peserta yang hadir mengenai pernikahan dini semakin mendalam karena dibahas dari berbagai sudut pandang.

Adapun dokumentasi dari kegiatan penyuluhan tersebut adalah sebagai berikut:

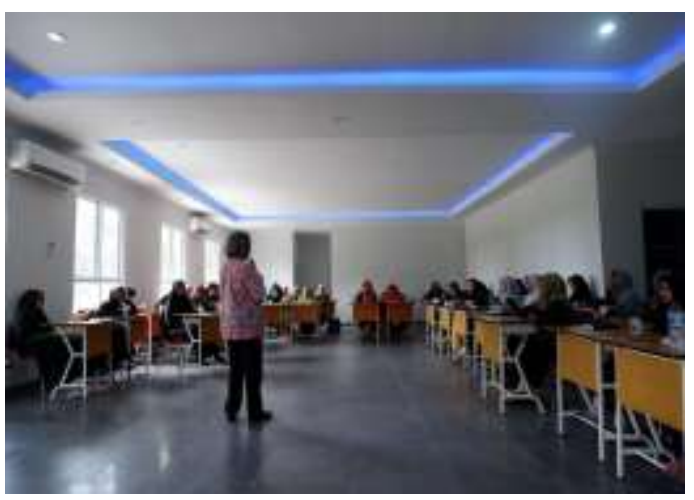

Gambar 1. Penyuluhan kepada guru

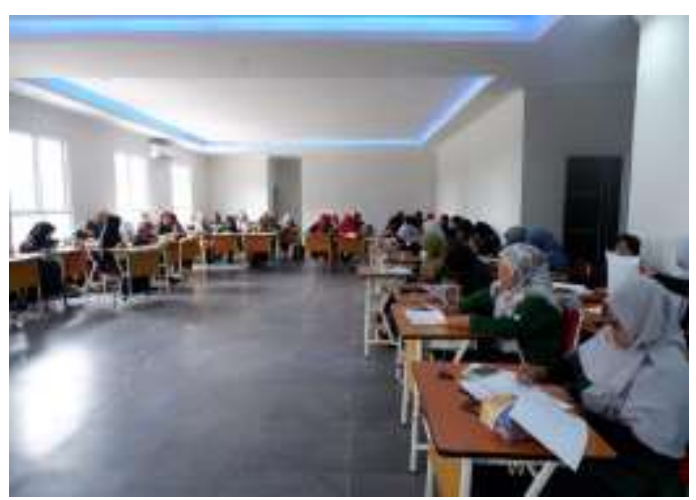

Gambar 2. Guru menuliskan pertanyaan

\section{HASIL DAN PEMBAHASAN}

Kegiatan penyuluhan dilakukan di perkebunan milik PT. Astra Agro Lestari, Pekanbaru, pada tanggal 27 November 2018. Kegiatan tersebut dihadiri oleh 35 guru perempuan yang mengajar di tingkat
Pendidikan Taman Kanak-kanak (TK) hingga tingkat Sekolah Menengah Pertama (SMP). Secara keseluruhan, penyuluhan berlangsung dengan lancar dan dipenuhi oleh antusiasme peserta melalui banyaknya pertanyaan yang diajukan serta tanggapan yang diberikan.

Pernikahan dini dapat terjadi karena kondisi masyarakat yang kurang paham mengenai dampak dari pernikahan dini yang ditimbulkan terhadap perempuan yang belum siap secara fisik maupun mental dalam pernikahan dini. Resiko yang cukup tinggi terjadi terhadap perempuan usia dini, seperti: kematian ibu setelah melahirkan karena belum siapnya organ reproduksi, hilangnya peluang sebagai individu untuk produktif, hilangnya identitas diri karena usia yang masih dini belum siap untuk melakukan peran ganda, tekanan psikologis saat melihat perbedaan aktivitas dengan teman sebaya seperti teman sebaya yang memiliki waktu bermain lebih banyak, rentang mendapat perlakukan kekerasan dalam rumah tangga sehingga menimbulkan konflik dalam dirinya, dan resiko-resiko lainnya. Jadi, dampak dari pernikahan dini selain terhadap kesehatan yang dapat menimbulkan kematian, muncul juga tekanan psikologis dalam melakukan peran yang belum siap.

Usia yang masih dini membuat remaja belum mampu berfikir panjang untuk tindakan yang dilakukan, kerugian secara mental dapat dirasakan oleh anak perempuan menjadi lebih besar, karena: 
Volume 2, Nomor 1, Tahun 2020 Hal 321 - 329

terikat dengan perannya sebagai ibu dan mengasuh anak, peran sebagai istri, peran sebagai menantu dari keluarga yang pola asuhnya mungkin sangat berbeda dengan pola di keluarganya.

Dalam liputan 6.com, Jakarta, dijelaskan ada beberapa kerugian jika terjadi pernikahan dini, seperti beberapa hal berikut: (1) Tanggung jawab, (2) kehidupan remaja, (3) perceraian, (4) pendidikan, (5) mengasuh anak. Tanggung jawab sangat berhubungan erat dengan peran mereka yang menikah muda dalam hal mengurus dan membesarkan anak-anak. Peluang mengembangkan diri menjadi terbatas karena tanggung jawab penekanannya dalam mengurus keluarga. Sementara mereka sebenarnya belum siap untuk melakukan peran ganda dalam keluarga. Dengan menikah dini, berarti ada masa remaja, masa bergaul dan bercengkrama dengan anak seusianya menjadi hilang, karena peran yang menjadi besar. Menikah dini mungkin akan menghilangkan kehidupan remaja yang menyenangkan. Hal ini dapat mempengaruhi pertumbuhannya sebagai individu. Dalam banyak kasus, mereka dapat menjadi warga negara yang tidak bertanggung jawab. Ini mungkin berhubungan dengan ketegangan dan rasa stres yang dialami terlalu dini, ketika pikiran mereka belum mampu untuk mengatasinya. Dampak sosial yang ditimbulkan dengan adanya pernikahan dini, dapat berkontribusi terhadap perceraian. Karena ada kalanya pernikahan dini terjadi belum tentu kedua belah pihak orangtua menyetujui. Pernikahan dilakukan hanya untuk mencegah supaya tidak menjadi buah bibir bagi lingkungan. Di luar itu, perceraian sering terjadi. Pada pernikahan dini, yang paling merasakan pendertiaan ini biasanya perempuan. Karena mereka harus mengasuh anak, mendapat cemooh dan kurang diterima di lingkungan, sebaliknya yang pria dengan mudahnya terbebas dari apa yang terjadi.

Pengalaman yang mereka rasakan setelah menikah, bisa jadi untuk sesaat menyenangkan karena apa yang mereka inginkan tercapai. Dampak sosial dan kehidupan yang mereka jalani mungkin tidak semudah pernikahan yang mereka lakukan, karena mereka tidak pernah berfikir mengenai resiko dari keputusan yang dilakukan. Usia yang masih muda dan harus memikul kehidupan yang tidak terbayangkan sebelumnya, berpeluang membuat mereka mudah tersulut pertengkaran, karena sebenarnya mereka memang belum siap secara mental. Peluang untuk bercerai menjadi akan dengan mudah terjadi. Terlebih jika ekonomi atau kebutuhan mereka tidak terpenuhi sebagaimana yang mereka nikmati dengan orangtua, dapat juga menjadi hal yang memicu perceraian. Beberapa keluarga muda yang menikah dengan mudah bercerai dan menikah lagi dengan pria lain. 
Volume 2, Nomor 1, Tahun 2020 Hal 321 - 329

Pernikahan dini yang terjadi, berarti merampas kebebasan mereka yang selama ini mereka miliki. Seperti mengikuti pendidikan, memiliki teman seusianya untuk bercengkrama, hal-hal tersebut tidak mungkin lagi mereka dapat lakukan. Karena teman-temannya tidak mungkin dapat bergabung lagi, karena tugas dan tanggung jawabnya telah berbeda. Temannya belajar, sementara dirinya mengurus anak dan keluarga. Sangat berbeda tujuannya. Kalaupun kembali mengikuti pendidikan dapat dilakukan malam hari, jika memiliki motivasi yang kuat.

Tugas baru yang menuntut tanggung jawab adalah mengasuh anak, karena di Indonesia menganut aliran patriakat sehingga sering kali tugas pengasuhan diserahkan kepada ibu. Tak dapat dibayangkan kalau pengasuhan anak diserahkan penuh kepada dirinya (anak perempuan). Sementara selama proses untuk memiliki anak, belum tentu di daerahnya ada pembekalan bagaimana cara mengasuh anak. Pasangan muda yang mungkin secara sosial-emosional tidak siap harus merawat anak termasuk bagaimana mereka memberikan asupan gizi yang seimbang. Dapat disimpulkan, bahwa kerugian dan dampak negatif dari pernikahan dini sangat kompleks, seperti benang kusut. Mereka sangat membutuhkan yang namanya pendampingan dan pencerahan dalam menyongsong kehidupan yang mereka lalui dengan mengisi dan mengembangkan potensi diri. $\mathrm{Hal}$ ini hanya dapat dilakukan, masyarakat yang peka dengan kebutuhan remaja, bagaimana mereka dapat mengisi diri dengan hal yang positif, melihat peluang dan kesempatan yang tersedia di daerahnya masing-masing. Seperti pemain sepak takraw Indonesia yang telah meraih prestasi. Bagaimana Lena dan Leni sebagai anak kembar dari keluarga dengan ekonomi yang tidak mungkin dapat melanjutkan sekolah, tetapi mengambil inisiatif untuk bekerja sebagai pencuri piring maupun pencuci pakaian tanpa ada rasa malu. Olahraga Sepak Takraw memberi peluang bagai mereka untuk hidup lebih baik, bangkit dari kehidupan finansial yang terpuruk. Hal ini dikarenakan mereka menyadari bahwa orangtua mereka memiliki keterbatasan. Contoh yang seperti ini perlu diperkenalkan kepada anak-anak remaja di pedesaan. Sehingga keinginan biologis yang belum terkontrol dapat dialihkan kearah yang lebih bermanfaat.

Hal yang dibutuhkan remaja yang menikah dini adalah pencerahan dari orang dewasa di sekelilingnya dan tidak menghakimi keadaannya. Bagaimanpun, mereka juga perlu diperhatikan dan dilindungi haknya sebagai bagian dari masyarakat. Seperti aktivitas yang dilakukan kelompok laskar sentosa pelangi, mencerahkan mereka yang masih remaja, melakukan pembekalan, kampanye ke sekolah-sekolah dan kerjasama dengan posyandu kesehatan 
Volume 2, Nomor 1, Tahun 2020 Hal 321 - 329

untuk memaparkan bahwa pernikahan dini lebih banyak kerugian dan dapat dipastikan pencegahan biayanya jauh lebih murah.

\section{SIMPULAN}

Kesimpulan yang dapat diambil adalah bahwa pernikahan dini lebih banyak kerugian yang ditimbulkan, seperti: meningkatnya jumlah kematian setelah melahirkan, meningkatnya perceraian, menghasilkan generasi baru yang tumbuh-kembangnya cenderung tidak sesuai dengan tugas-tugas perkembangan yang seharusnya, beban sosial keluarga, dan kerugian dalam jangka panjang secara sosial-emosional.

Beberapa saran-saran berikut diharapkan dapat menjadi pengingat bagi orangtua, guru dan remaja itu sendiri, agar dapat melakukan hal-hal yang mampu menghindarkan mereka dari kejadian pernikahan dini, yaitu seperti:

1. Menjalin komunikasi dengan orangtua, guru, secara terbuka.

2. Jika remaja jatuh cinta, mereka diharapkan berkonsultasi dengan orangtua, guru, supaya mereka mampu menjalin relasi yang dekat tetapi tidak melakukan hubungan yang beresiko.

3. Mengikuti kegiatan yang positif di lingkungan sekolah serta masyarakat.

4. Memikirkan secara matang dampak yang ditimbulkan pernikahan dini.
5. Jika begitu kuat keinginan untuk menikah, setidaknya menunggu usia yang matang, sesuai dengan perudang-undangan yang berlaku di Republik Indonesia.

6. Bergaul dengan kelompok yang memberikan motivasi.

7. Orangtua mengontrol keadaan dan perubahan perilaku anak-anaknya.

8. Sekolah membuat program terpadu yang dapat mencerahkan pikiran dan tindakan orangtua dalam mengasuh anak-anaknya.

9. Kerjasama antara orangtua dan sekolah dalam membangun generasi yang cerdas dalam bertindak.

\section{UCAPAN TERIMA KASIH}

Ucapan terima kasih kami sampaikan kepada:

1. Universitas Kristen Indonesia, sebagai afiliasi penulis yang memberikan keleluasaan waktu bagi penulis untuk melakukan kegiatan pengabdian kepada masyarakat ini.

2. PT. Astra Agro Lestari yang memberikan ijin serta mengarahkan sekolah di perkebunan dalam mengikuti kegiatan pengabdian kepada masyarakat ini. 
Volume 2, Nomor 1, Tahun 2020 Hal 321 - 329

3. Yayasan Astra Agro Lestari yang membawahi unit organisasi sekolah di perkebunan kelapa sawit, sehingga para guru di perkebunan dapat ikut serta pada kegiatan ceramah maupun diskusi di pengabdian kepada masyarakat ini.

\section{REFERENSI}

https://www.kompas.tv/content/article/242 11/video/opini/penyebab-terjadinya pernikahan-dini. Kompas.tv 17 april 2018. Pernikahan Dini. Di unduh 18 Agustus 2018, pukul 12.00 .

http://video.metrotvnews.com/kickandy/9K54zj3k-cegah-pernikahan-dini- pemuda-ini-dirikan-posyandu-remaja.

Di unduh 12.30. 18/8/2018.

https://www.liputan6.com/health/read/257 1677/6-kerugian-menikah-dini. Di unduh tanggal 18/8/2018, pukulu.13.15.

Metro.TV. Pemuda Berprestasi. 18/8/2018. Metro TV pukul.15.00

Limbong, Mesta. (2017). Perkembangan Peserta didik. Jilid I. Modul untuk Mahasiswa, tidak dipublikasi.

Santrock. 2012. Life Span. Terjemahan Jakarta: Erlangga.

Undang-Undang nomor 23 tahun 2002. 2013. Perlindungan anak. Surabaya: kasindo Utama. 